\title{
The rise of the British pharmaceutical industry
}

\author{
Jonathan Liebenau
}

Department of Information Systems, London School of Economics, London WC2A 2AE

Jonathan Liebenau, PHD, lecturer in information systems

BrMed f 1990;301:724-8, 733
The growth of the modern pharmaceutical industry took place largely in western Europe and the United States. At the beginning of the nineteenth century little distinction could be found between, on the one hand, the American corner shop that sold drugs, the British chemist's shop, or, in Germany and elsewhere, the apothecary and, on the other hand, importers, manufacturers, and wholesale drug traders. Drug exchanges operated in major trading ports, so in Philadelphia, New York, London, and Amsterdam the trade had a self governing body that helped to minimise bad business practices, especially overcharging by shippers. For the most part, however, trade consisted of representatives or proprietors of large pharmacies going to the ports when shipments came in and bargaining directly with shipping agents for bulk purchases. These purchases would typically be processed in a very preliminary fashion, cleaned, sorted, and packaged, and then enter the wholesale trade as materia medica ${ }^{1-3}$ Companies such as Allen and Hanbury, Jacob Bell, and Thomas Morson, all small London operators, established standard working arrangements whereby they would conduct retail trade from their city shops and maintain warehouses with compounding rooms from which they would serve as wholesalers to retailers in south east England.

Trade was well established by the early years of the century with most suppliers offering complete ranges of medicines but perhaps concentrating on the larger scale processing of a few types of items. So when Thomas Morson returned from studying in Paris, where he came under the influence of Pelletier and others who were working on quinine products, he began to cultivate a reputation for processing quinine for the English market. Similarly, Allen and Hanbury began a company practice of processing oils as part of their efforts to supply their market with some lines that were less well served previously. ${ }^{4}$

As pharmaceutical firms grew from apothecary shops to family companies and then to large corporations, their relation with the medical community also changed. Pharmacists held a tenuous place in the medical world of the nineteenth century, although they provided important services to those members of the public who did not use doctors and supplied those who did with medicines. Towards the end of the century drug makers distanced themselves from pharmacists and their informal practice of medicine. As the distinction grew between reputable manufacturers who sought the professional market-"ethical" pharmaceutical producers - and the popular "patent medicine" makers, the large companies looked for a compromise between the two. They hoped to establish reputations for quality but also to reap the profits from patent or proprietary medicines. ${ }^{45}$

\section{Drastic remedies and maintaining the balance}

Drug use has always been associated to some extent with therapeutic theory, although less directly than is often thought. In the early nineteenth century medicines were compounded and administered both

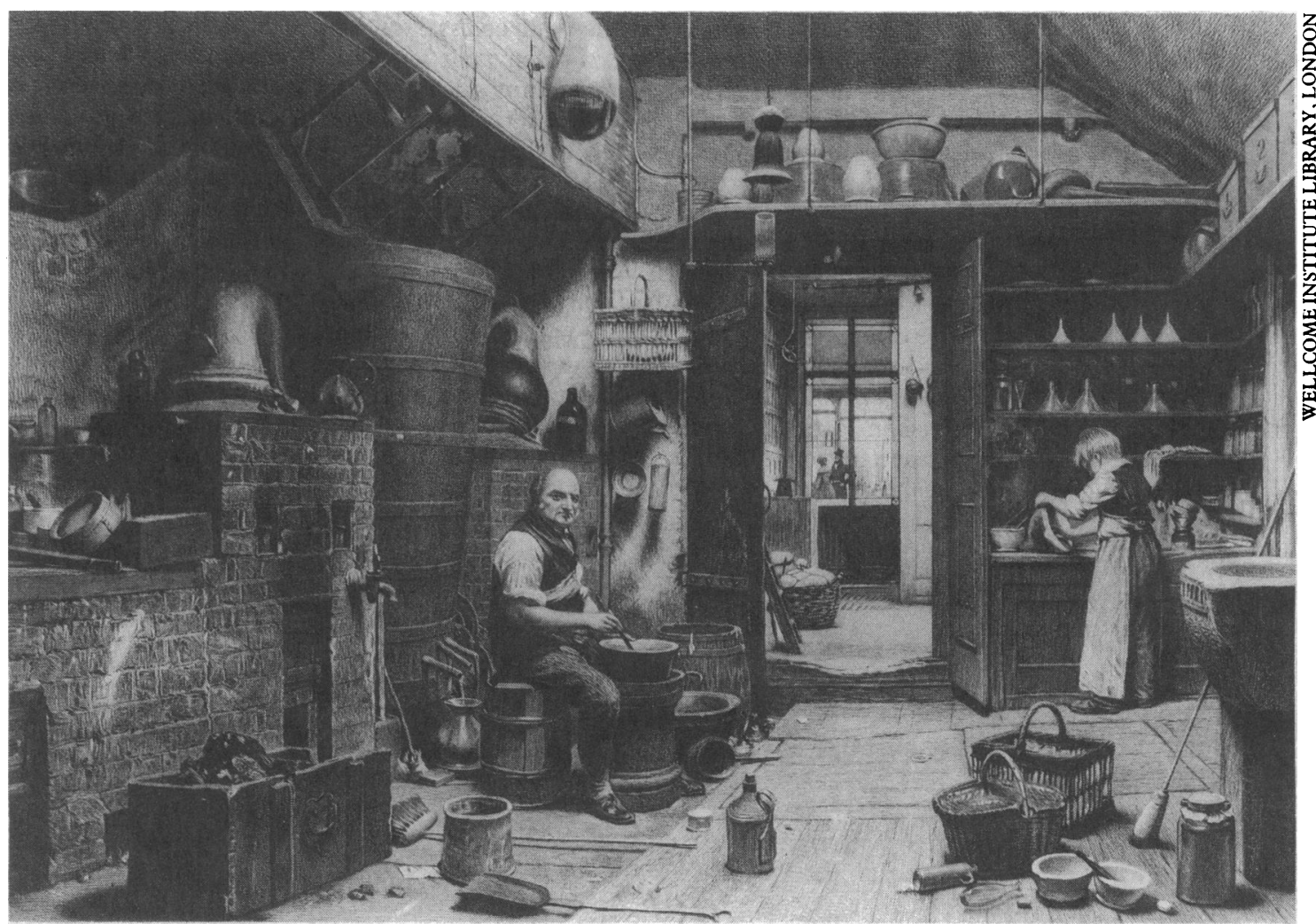



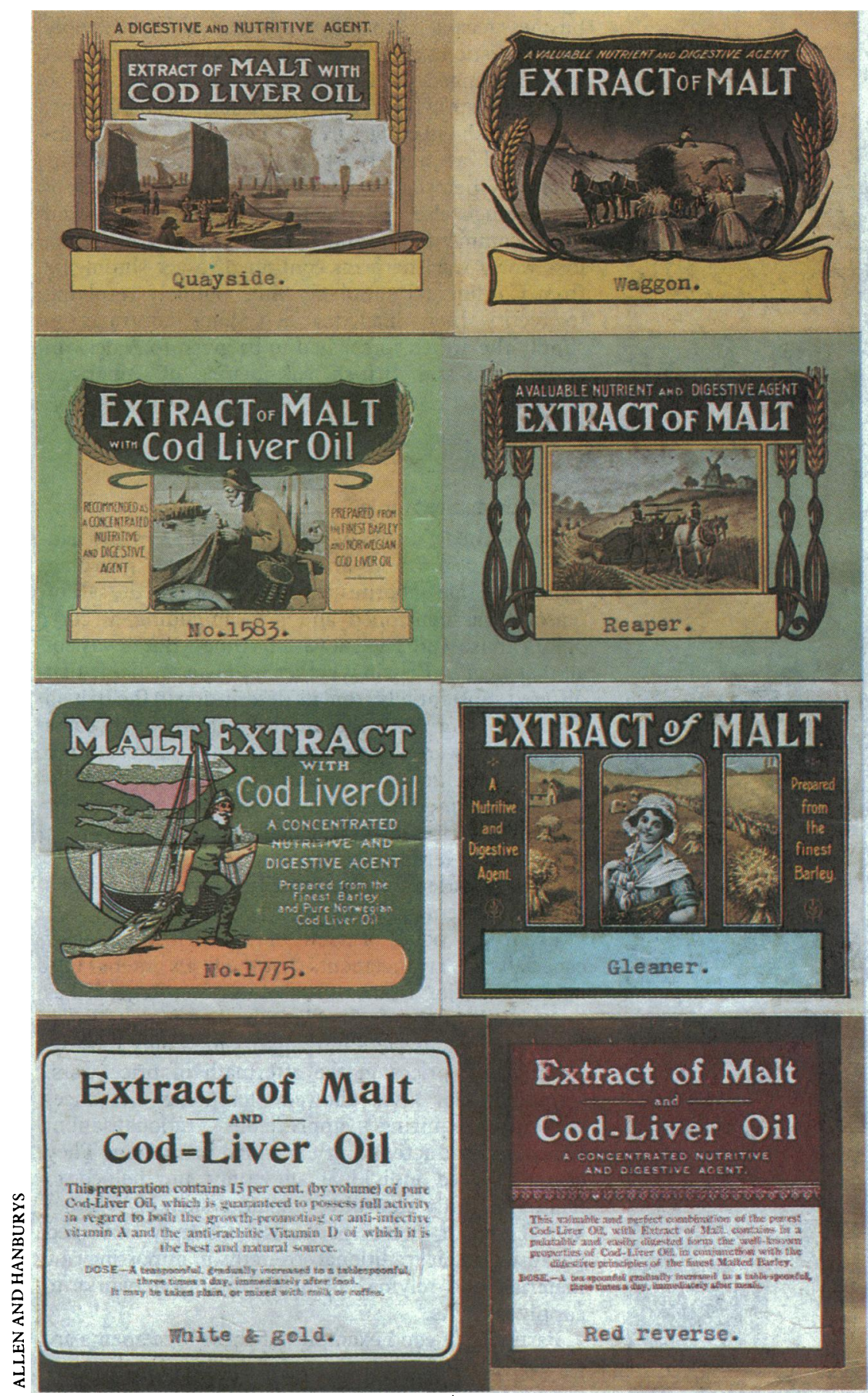

Malt extract with cod liver oil was an important specialty in the early nineteenth century body was as a system of intake and outgo. Doctors and patients could see and judge excretions or appetite; they therefore seemed an obvious monitor of health. Treatment, as a result, concentrated on diet and excretion, and perspiration and ventilation, as the aspects that could be controlled to produce a stable system. If a person had a wound, for example, he or she might be treated with a salve locally, but the holistic implications for the body might well necessitate the administration of a stimulant in addition.

Enormous quantities of medicines were consumed in order to maintain or re-establish health. Special drugs were also administered in life crises or at changes of the season, when a patient's body was more liable to lose its healthy equilibrium. Cathartics, for example, were given in the spring and autumn to help the body adjust to these cyclical changes. Mercury treatments and bleeding were the most common severe treatments, both producing dramatic effects.

This therapeutic framework was not necessarily interpreted by a doctor: in the first half of the nineteenth century many people avoided doctors altogether and consulted pharmacists. Preference for self dosing and the lesser expense of druggists stimulated trade in patent medicines. These remedies, often standard preparations of common drugs sold by brand name or unusual concoctions of stimulants, alcohol, and flavouring sold exceedingly well. Most of the drug companies that originated in pharmacies or wholesalers depended on patent preparations for the bulk of their profits. ${ }^{126}$

Doctors increasingly relied on pharmacopoeias, a trend that encouraged the growth of a market for standard preparations and, conversely, a smaller one for drugs compounded in apothecaries. Apothecary practice also changed because visiting salesmen began to deliver orders frequently, and this, together with increasingly reliable transport, meant that pharmacies began to stock smaller quantities of drugs. Changes in treatment towards using more specific drugs with measured doses also encouraged the introduction of the standard preparations produced by companies. ${ }^{2}$

\section{Britain's failure to develop}

The British pharmaceutical industry in the nineteenth century was composed primarily of several small firms serving domestic consumers and exporting to traditional markets. They relied largely on raw materials imported from trading nations and tropical colonies or on standard chemicals and byproducts. The typical range of products would include galenical preparations; alkaloids; numerous creams, infusions, and dressings; and hundreds of miscellaneous medications. Leading firms such as Whiffen, Morson, Allen and Hanbury, May and Baker, and others in Britain all dealt in largely the same sort of products. By the 1830s some companies specialised in products such as alkaloids, as was the case with Morson's quinine trade in London and Macfarlain's opiates business in Edinburgh. For the most part, however, the products on offer overlapped among the competing firms. They also often listed a full range of medicines and acted as suppliers of products from associated companies if they could not cover the range adequately by manufacturing themselves. ${ }^{4}$

All of these companies were small, usually employing fewer than 100 workers, and, with the exception of a few scientifically minded proprietors such as William Allen or Thomas Morson, there was little commitment to pharmaceutical investigation or product development. Even those that did establish laboratories never integrated them into the normal course of business. ${ }^{4}$

In Britain this began to change with the grounding in 1894 of the Wellcome Physiological Research models of disease were reconciled by the principle that every part of the body was related inextricably to every other. The early nineteenth century conception of the 

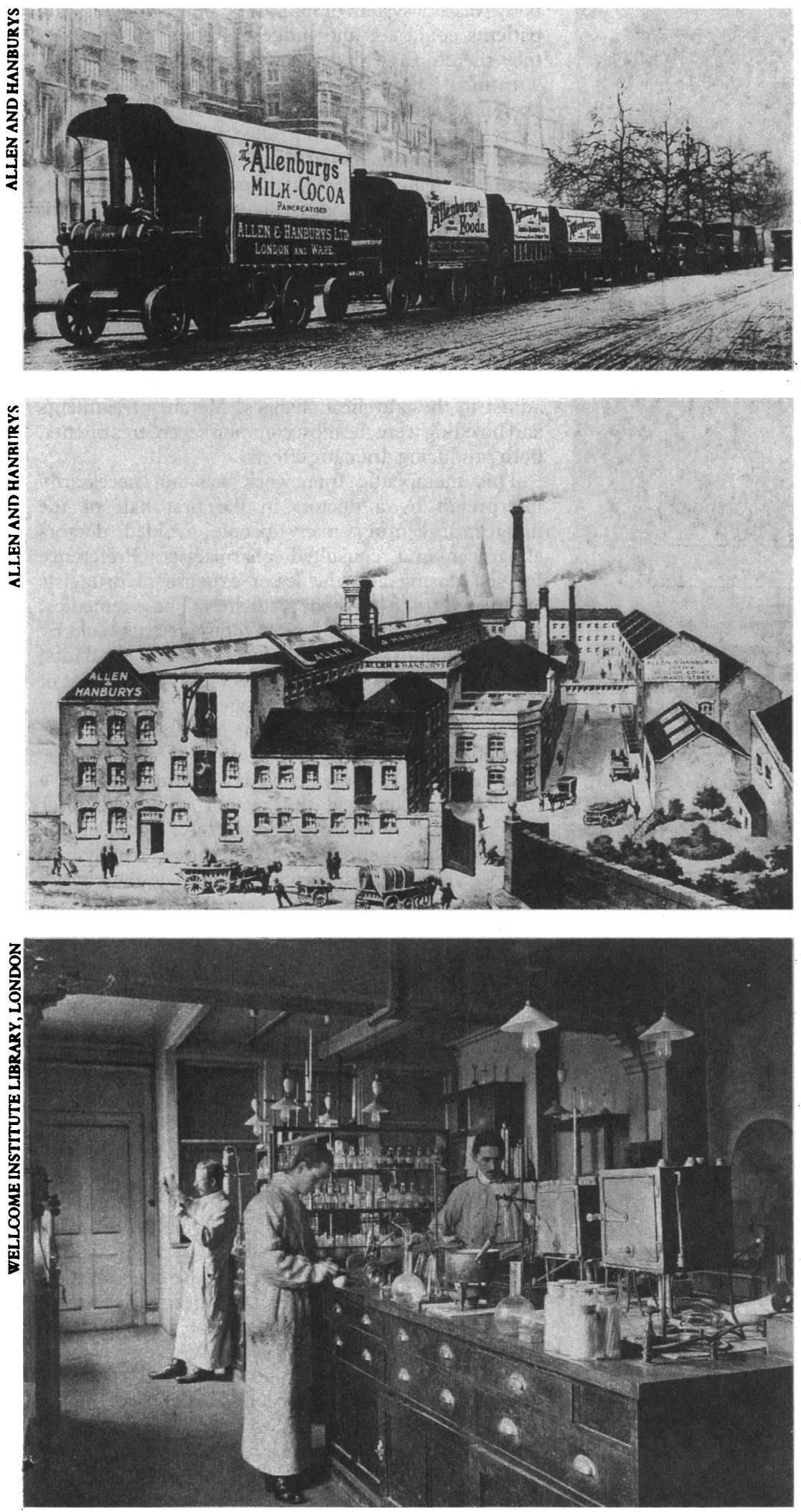

Top: Allen and Hanburys's

steam motors

Centre: Allen and Hanburys's factory in Bethnal Green in the 1890s

Bottom: Pharmacology

laboratory of the Wellcome

Physiological Research

Laboratories (1908) business terms, reasonably stable but unable to supply the domestic market with many of the products that had so changed the industry abroad. There were no major industrial laboratories for product development, and British manufacturers, who had been complimented at numerous trade exhibitions for the quality of their standard products, seemed incapable of doing much else. This inability was recognised and much commented on, but little changed. During the first world war the firms continued to get shipments from Continental suppliers while publicly resolving to rectify their inadequacies. Major contracts to supply the armed forces had to be given to American companies, and British subsidiaries of American manufacturers such as Parke Davis did a booming business. ${ }^{45}$

\section{The German example}

The United States, Switzerland, and Germany had long had vague and unenforceable rules guarding against the sale of harmful agents. In Britain the sale of poisons was controlled and laws intending to curb opium abuse were tried at various times. But it was not all that clear in Britain whether selling a medicine that differed substantially from its description in the British Pharmacopoeia was illegal. In various test cases pharmacists were able to argue either that the customer had not specified that medicine exactly, or that the Pharmacopoeia did not have what was wanted, or that its description was inadequate. This vagueness prevailed in Germany also; and in the American states legislation varied widely, but all had weak provisions for enforcement. ${ }^{12}$

From the point of view of the British industry especially the arrangements that the firms entered into became a major aspect of their business. Regarded as "remedial" and "defensive" rather than monopolistic, these agreements were initially oriented only towards raising field prices in the aftermath of price wars. Combinations also allowed temporary alliances without requiring appreciable rationalisation, increased productivity, or expanded marketing. They also preserved individual autonomy and helped to maintain family control. Companies such as Whiffen and Howards were particularly deeply involved because of their traditional strengths in importing raw materials and relying on their shipping networks to supply markets. ${ }^{4}$

Particularly good examples of these agreements are the caffeine, iodine, and camphor cartels. The first two were a result of the reaction of firms to the need for combinations and the third is an example of the fragility of these agreements owing to their inability to address the cause and not just the symptoms. These cartels were typical of arrangements used by German and British companies to try to stabilise trade, but they served the two national industries quite differently. To the Germans they opened markets overseas, and they took advantage of superior British supply routes. This facilitated their growth, especially by opening up new areas. For the British, however, the agreements were usually drawn up with the intention of covering products that were already being imported, processed, and sold or exported. Their advantage was primarily in fixing prices, and it was a defensive strategy that staved off competition. British interests were directed at Imperial territories - to postpone German commercial encroachment-and the United States - in the naive hope that they could regain their early nineteenth century position as major suppliers. What the British manufacturers failed to understand was that by emulating the German industry American manufacturers, with effective governmental aid, were being transformed fundamentally. ${ }^{4}$ 
Foundations of a modern industry

In contrast with Germany and America, Britain had virtually no regulation covering medicines until well after the first world war. Other than food and drug laws prohibiting gross acts of adulteration, and even these were difficult to define and enforce, manufacturers had virtually free hands. Nor were there many suggestions that British companies should be inspected as American firms were or that their products should be tested and certified as German law prescribed. There was no outcry; that is, not until the relative weakness of the British pharmaceutical industry was dramatically made known by the outbreak of war. ${ }^{14}$

A survey of the research capacity of five of the leading British companies was carried out in 1942. This showed a wide variance in size and emphasis. In the period 1936-41 May and Baker held the lead in the group for the number of British patent applications (40), but their rate of publication was slow, having produced only 11 scholarly articles with a staff of 58 university graduates, 15 of whom held doctorates. Burroughs Wellcome had placed only six patent applications, but their 66 degree holding scientific staff, 24 of whom held doctorates, had published 220 articles in journals during the period. Glaxo stood between these two research leaders with a less well qualified scientific staff (eight held doctorates) but a publication record of 345 articles and 13 British patent applications. BDH Chemicals had only five workers who held doctorates but produced 32 publications and seven patents; even so they were generally regarded as having little research potential. Boots was similarly regarded. They had a very large staff, amounting to almost 270 scientific workers, 24 of whom held doctorates. Nevertheless, they published only 10 articles and applied for only 12 patents over the five years. ${ }^{7}$

It was in this context that efforts to capitalise on penicillin took place. Alexander Fleming initially observed the antibacterial effect of the Penicillium notatum mould in 1928 . He noted its potential, but there was little more done with penicillin until 1939 when Ernst Chain looked to Fleming's work for additional data on lysozyme and turned Howard

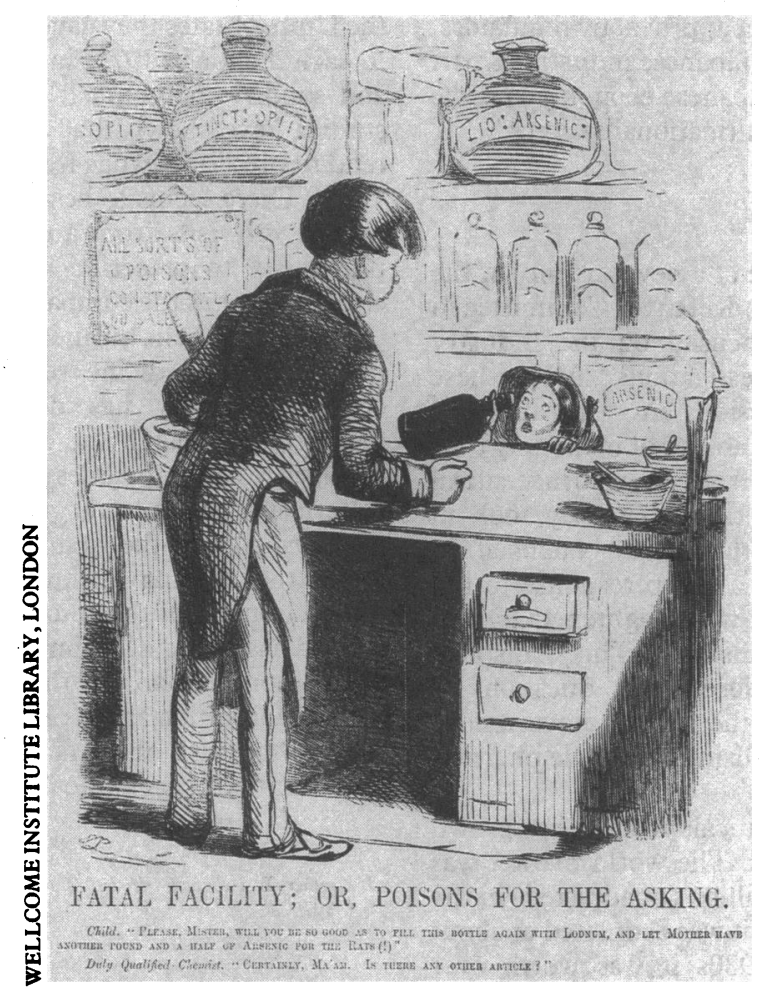

\section{0s}

- 1900: Karl Landsteiner introduces the basic $A / B / O$ system of human blood types

- 1902: William Bayliss and Ernest Starling isolate "secretin," one of a class of substances for which, in 1905, Starling was to coin the word "hormone"

- 1903: Willem Einthoven introduces his string galvanometer, forerunner of the electrocardiograph

Florey's laboratory in Oxford into a penicillin research centre. Not much was done to produce the drug, the traditional version of the story of the development of penicillin tells us, until Florey and his colleague Norman Heatley travelled to the United States in the summer of 1941 and brought penicillin to the attention of some American manufacturers-in particular Pfizer, Merck, Squibb, and Lederle-along with United States federal government science administrators at the Office of Scientific Research and Development. From that time several changes took place, in particular in the strains used and the techniques of mass production by deep fermentation at the government laboratory in Peoria, Illinois. ${ }^{\text {? }}$

\section{Antibiotics and postwar growth, 1940-70}

In Britain the bitterness of the penicillin episode stayed with the industry into the 1950 s. Demoralised by the criticisms associated with penicillin and insecure of its place within the new National Health Service, the industry suffered an invasion of foreign takeovers of old firms, such as the acquisition of Morson's by Merck Sharp and Dohme and numerous consolidations such as the ones which built Glaxo into a major drugs manufacturer. There were of course a few important contributions by the British industry during the 1950s in topics such as antibiotics and in research on cortisone, and Beechams did build itself by concentrating on penicillin production. The thalidomide tragedy, however, did unprecedented damage to the public image of the industry and forced major reassessments of how practice in industry "allowed it to happen." The answer to that question, like the answer to the question of how British companies lost the lead in antibiotics, is that it happened as a direct consequence of the history of the industry. ${ }^{67}$

Two new types of products stimulated the growth of the industry after the second world war: antibiotics and psychoactive drugs. They provided massive new markets on which to base further corporate growth and changed the role of research from an opportunistic to a necessary function. The success of the American cooperative effort to produce penicillin on a large scale is only part of the story. It is important to understand the less successful efforts of the Therapeutic Research Corporation, a consortium of British manufacturers and of German and French researchers, in order to explain the subsequent distribution of strengths in the industry. After the war and the rise of Glaxo, Beechams, and Boots in the United Kingdom; the rise of Pfizer and Lederle in the United States; the re-establishment of Schering, Hoechst, and Bayer in Germany; and the continuing success of the three major Swiss manufacturers, the industry took on a prominent new international and transnational character. ${ }^{67}$

During the second world war the drug industry was challenged to produce penicillin on a large scale. The use of antibiotics radically altered therapeutics; it also 
Each lozenge contains 500 Units of Penicillin (Calcium Salt) in a flavoured sucrose base.

\section{DIRECTIONg. To be used as directed by the physician. \\ MANUFACTURED IN ENGLAND BY \\ ALLEN \& HANBURYS LTD LONDON E2}

The age of antibiotics

fundamentally affected the drug manufacturers. The production of antibiotics was ordinarily more complex than that of the biological drugs or even chemotherapeutic drugs, and hence even larger and more highly trained scientific staffs had to be assembled. Moreover, the subsequent search for other antibiotic drugs necessitated creative fundamental research and product development on a greater scale than ever before. Their proliferation was then matched by those of the psychoactive drugs of the 1950s. But none of this was unprecedented. The company structure in which this took place, the laboratories and testing facilities, even the special relationships between marketing departments and doctors, had all been established in the years preceding the Great Depression. ${ }^{2}$

The thalidomide tragedy gave fuel to a range of opponents of drugs manufacturers, who objected to their high profits, their collusive behaviour, and their evidently inadequate checks on safety. A new relationship with the government was supposed to have emerged, but the real effect in the 1960s was to put the industry under stringent scrutiny over prices and to slow the process of drug approval by regulators. The 1960s saw the rise of the Japanese industry as part of the general boom in the Japanese economy and the broadening of the base for multinationalisation. ${ }^{89}$

\section{New scrutiny}

The 1960s also saw the rise of a new scrutiny of the pharmaceutical industry. The Kefauver Committee in the United States Senate focused on the industry in their anti-monopoly investigations. After these investigations many discussions in the industry revolved around how to avoid abuses of monopoly type power while continuing to reward pharmaceutical companies for the financial risks that they took in developing new medicines that were beneficial to society. In Britain there was a sharp response to the committee's findings, which was heightened by the impact of the thalidomide disaster. The Sainsbury Committee in 1967 considered the question of pharmaceutical pricing, and the Labour government toyed with the idea of nationalising the whole pharmaceutical industry.9-11

The size of the pharmaceuticals market has grown tremendously in recent years. The world market was estimated to be around $\$ 10$ billion (unadjusted) in the mid-1960s. In the mid-1970s it was estimated at about $\$ 36$ billion. By the early 1980 s it was worth over
$\$ 80$ billion, most of it in sales to the developed market economies. The market is dominated by a small number of very large companies organised on a multinational basis and located in the United States, Germany, Switzerland, the United Kingdom, and Japan. There is continuing regulation over the introduction of new products in all of the largest countries, and most national governments regulate the prices that can be charged. The European market is divided along national and regional lines and accounts for just over a fifth of the world market. European production, however, accounts for more than a quarter of world output; it is concentrated in 33 firms, which have a capacity for serious product innovation. Additionally, there are about 1500 other manufacturers that produce primarily out of patent drugs or specialised products or work under licence. . $^{8-10}$

\section{Information, image, and reminder gifts}

Drug consumption varies internationally according to cultural and historical patterns. These differences have a great deal to do with attitudes towards therapeutics and towards the role of doctors and pharmacists. Other variations of special importance follow economic and demographic trends. Drugs for treating the diseases of old age have come to dominate, as might be expected, in those countries with prosperous, generally healthy, but aging populations. ${ }^{9}$

As for drug marketing, we have seen the evolution of an established manufacturing sector into a high technology industry and its adaptation of a scientific image that was most useful for marketing its products. The question of the control of information about drugs continues to plague the medical world and its regulators. Recent studies in Britain and the United States have shed some light on the continuing role of manufacturers as sources of information. Company representatives still supply most information about the existence and cost of drugs, and whereas scholarly periodicals may be of greater influence and regarded as more reliable sources about the efficacy of new medicines, they are less accessible. ${ }^{112}$

Through the systematic use of trained representatives, the detail men, drug companies continue to maintain close personal contact with doctors. They frequently give doctors gifts and "reminder items." In the United States they gave away almost 200 small gifts to each doctor in 1973 , just to establish a relationship and solidify the contact. Marketing and sociological studies have shown that doctors who see detail men tend to prescribe drugs from their companies after the visits. There seems to be a direct relation between the number of visits from a particular company and the propensity to prescribe a particular drug, and this closely matches the company's advertising expenses. ${ }^{811}$

From small scale businesses almost indistinguishable from patent medicine sellers the modern pharmaceutical industry has developed sophistication in marketing to match the complexity of the products. While British companies grew more slowly than the American, Swiss, and German industries during the period after the first world war, in more recent times the leading manufacturers have become so international that the country where headquarters are located has become less important. With the increasing internationalisation of the industry techniques for using information about pharmaceutical products have tended to push manufacturers into an ever more important position in the medical community. 1 Kremers E, Urdang G. History of pharmacy. 4th ed. Philadelphia: Lippincott,
1976.

continued on page 733 
34 McPherson K. Statistics: the problem of examining accumulating data more than once. N Engl f Med 1979;290:501-2.

35 Pocock SJ. Interim analyses and stopping rules for clinical trials. In: Bithell JF, Gippi R, eds. Perspective in medical statistics. London: Academic Press, 1981:191-214.

36 Glass GV. Primary, secondary and meta-analysis of research. Educational Research 1976;5:3-8.

37 Sacks HS, Berrier J, Reitman D, et al. Meta-analyses of randomised controlled trials. N Engl I Med 1987;316:450-5

38 Elwood PC. Randomised controlled trials: sampling. $\mathrm{Br} f$ Clin Pharmacol 1982;13:631-6.

39 Lovell RRH. Problems of interpretation in secondary prevention trials in coronary heart disease. Med $\mathcal{F}$ A ust 1977;14:224-6.

40 Gifford RH, Feinstein AR. A critique of methodology in studies of anticoagulant therapy for acute myocardial infarction. $N$ Engl 7 Med 1969;280:351-7.

41 Fletcher RH, Fletcher SW. Clinical research in medical journals. $N$ Engl f Med 1979;301:180-3.

42 DerSimonian R, Charette LJ, McPeek B, Mosteller F. Reporting on methods in clinical trials. $N$ Engl F Med 1982;306:1332-7.

43 Lavori PW, Louis TA, Bailar JC, Polansky M. Designs for experimentsparallel comparisons of treatment. $N$ Engl F Med 1983;309:1291-9.

44 Cobb LA, Thomas GI, Dillard DH, et al. An evaluation of internal-mammaryartery ligation by a double blind technique. $N$ Engl f Med 1959;260:1115-8

45 Patchell RA, Tibba PA, Walsh RJ, et al. A randomised trial of surgery in the treatment of single metastases to the brain. $N$ Engl $\mathcal{H}$ Med 1990;322: 494-500.
46 Roberts MM, Alexander FE, Anderson TJ, et al. Edinburgh trial of screening for breast cancer: mortality at seven years. Lancet 1990;335:241-6.

.

48 Fischhoff B, Lichtenstein S, Slovic P, Derby SL, Keeney RL. Acceptable risk. Cambridge: Cambridge University Press, 1981.

49 Rawlins MD. Trading risk for benefit. In: Mann RD, ed. Risk and consent to risk in medicines. Carnforth: Parthenon, 1989:193-202.

50 Committee on Proprietary Medicinal Products. The rules governing medicinal products in the European Community. Vol III. Guidelines on the quality, safety and efficacy of medicinal products for human use. Brussels: Commission of the European Communities, 1989.

51 Commission of the European Communities. Proposal for a council directive amending directives $65 / 65 / E E C, 75 / 318 / E E C$, and 75/319/EEC. Brussels: Commission of the European Communities, 1990.

52 Hill AB. Artificial pneumothorax on statistical trial: reply. Lancet 1937;i: 535-6.

53 Broader S. Controlled trial methodology and progress in treatment of the acquired immunodeficiency syndrome (AIDS). Ann Intern Med 1989;110: 417-8.

54 Medawar C. The wrong kind of medicine. London: Consumers Association and Hodder and Stoughton, 1984.

55 Collier J. The health conspiracy. London: Century, 1989.

56 Lewitt G, Brown PK, Tyrell DA. Controlled study of the effects of a homoepathic dilution of influenza vaccine on antibody titres in man. Complementary Medical Research 1989;3:22-4.

57 Anonymous. Biotechnology eclipsed? Nature 1990;343:494.

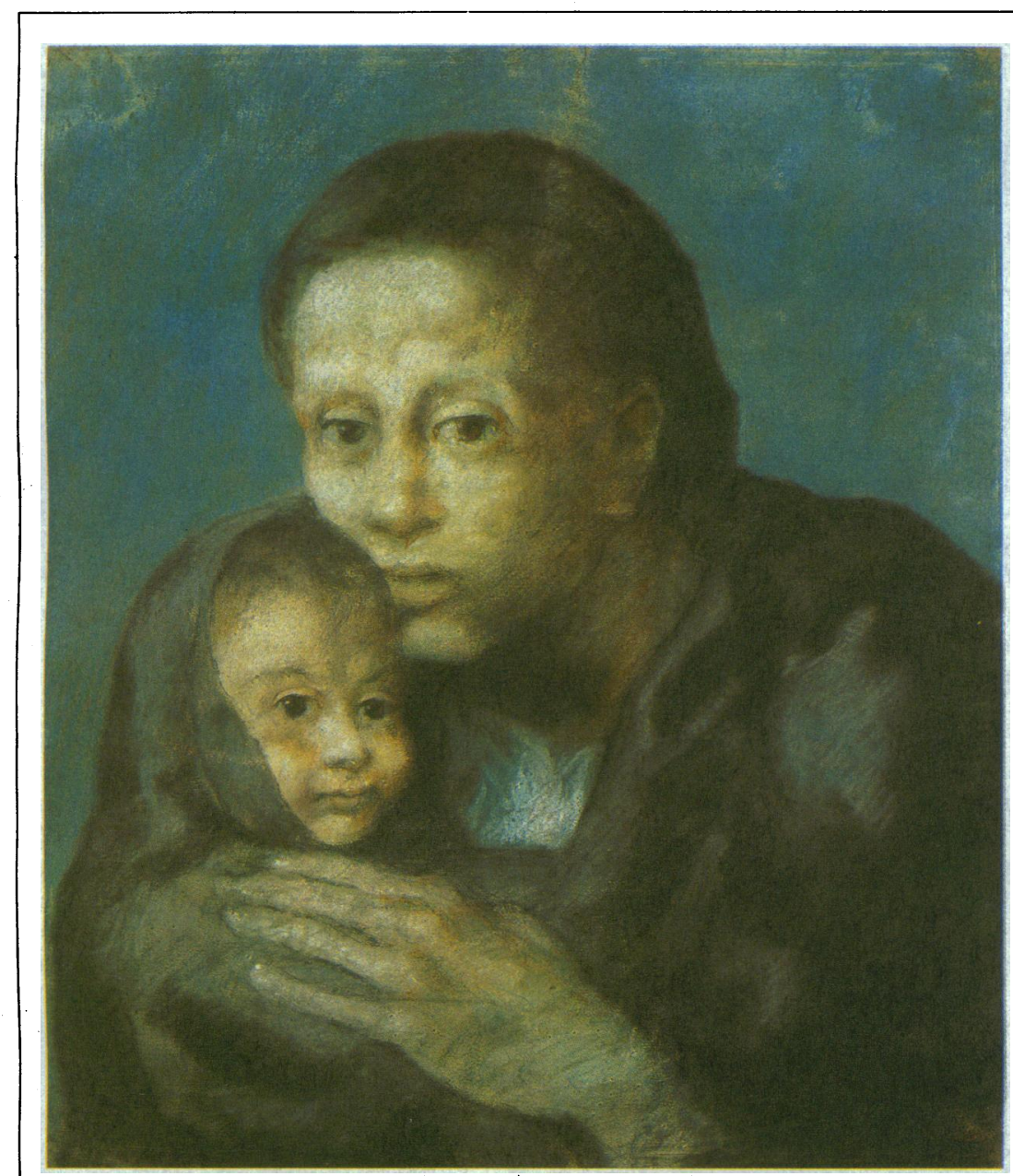

\section{The Sick Child (1903)}

\section{Pablo Picasso (1881-1973; Spanish)}

At the turn of the century Paris was the cutural centre of the avant-garde and the natural aim of any ambitious artist. Picasso arrived from Barcelona in 1900, alternating between the two cities for the next four or five years. This was a time when he was to suffer not only poverty but depression, which he translated into the works of his "blue," or classical, period. The themes of these pictures are usually poverty and despair, the subjects social outcasts.

One of the Spanish pictures of the blue period, the pastel "The Sick Child," is reminiscent of a Madonna and Child. But there the likeness ends. It is a picture of despair. The boy's face is so emaciated that his cheekbones almost protrude through the flesh and it is painful to meet his eyes. Although his mother is touchingly protective, she cannot conceal her anguish. In less sensitive hands this theme might have been sentimental, but Picasso has produced a haunting image. In particular the subtle use of blue over its entire range complements the subject and is an ideal symbol of poverty and sadness. Pastel is a notoriously difficult medium but Picasso uses it here with consummate skill. It seems extraordinary that a mere four years separate this gentle image from the aggression of "Les Demoiselles d'Avignon."

\section{CLASSIC OF THE DECADE}

1900: Sigmund Freud's Die Traumdeutung. Leipzig: F Deuticke.

\section{Rise of the British Pharmaceutical Industry}

continued from page 728

2 Liebenau J. Medical science and medical industry. The formation of the American pharmaceutical industry. Baltimore: Johns Hopkins University Press, 1987. 3 Mahoney T. The merchants of life. An account of the American pharmaceutical industry. London: Harper, 1959.

4 Liebenau J. Ethical business: the formation of the pharmaceutical industry in Britain, Germany and the United States before 1914. In: Davenport-Hines RPT, Jones G, eds. The end of insularity. Essays in comparative business history. London: Cass, 1988.

5 Liebenau J. Industrial R\&D in pharmaceutical firms in the early twentieth century. Business History 1984;26:329-46.
6 Davis W. The pharmaceutical industry. A personal study. Oxford: Pergamon, 1967.

7 Liebenau J. The British success with penicillin. Social Studies of Science 1987;17:69-86.

8 Burstall ML, Dunning JH, Lake A. Mulninational enterprises, governments and technology: pharmaceutical industry. Brussels: Organisation for Economic Cooperation and Development, 1981.

9 Burstall ML. The community's pharmaceutical industry. Brussels: European Communities Commission, 1985.

10 Silverman M, Lee PR. Pills, profits and politics. Los Angeles: University of California Press, 1974.

11 Temin P. Taking your medicine: drug regulation in the United States. Cambridge, Massachusetts: Harvard University Press, 1980.

12 Schwartzman D. Innovation in the pharmaceutical industry. Baltimore: Johns Hopkins University Press, 1976 